Reprod. Nutr. Dévelop., 1986, 26 (2 A), 441-452.

\title{
Sexual behaviour and gonadal activity during the year in the tropical Creole meat goat. \\ I. Female oestrous behaviour and ovarian activity
}

\section{P. CHEMINEAU (1)}

with the technical assistance of $H$. VARO and A. GRUDE

I.N.R.A., Recherches Zootechniques

97170 Petit Bourg (Guadeloupe), French West Indies.

Summary. An experiment was carried out over two consecutive years on 30 adult creole goats to determine if ovarian activity and oestrous behaviour varied seasonally and if feeding plane affected these responses.

The animals, maintained on a pangola (Digitaria decumbens) pasture with a stocking rate of $1,060 \mathrm{~kg}$ liveweight/ha, were divided into two groups : C (control) and $\mathrm{S}$ (supplemented). Every month pasture quality was assessed and the animals were weighed. Goats of group $S$ received a daily supplement of $0.3 \mathrm{~kg}$ of a commercial concentrate. Oestrous behaviour was monitored daily using a marking harness on a vasectomized buck in each group ; ovarian activity was observed by monthly laparoscopy.

Wide variations in pasture quality were observed from one month to another ; dry matter and crude fiber generally were elevated (40 and $32 \%$ ) and crude protein content was low $(6.6 \%)$. In spite of poor quality pasture, goats of both groups showed a liveweight gain $(\mathrm{C}:+30 \% ; \mathrm{S}:+41 \%)$ throughout the experiment.

During all of the experiment, more than $87 \%$ of the females ovulated monthly, and this percentage did not vary with the month ; the percentage of females showing oestrous behaviour (on average $82 \%$ ) varied significantly with the month and was lower than ovarian activity, indicating existence of silent ovulations. Supplementation had no effect on monthly ovarian activity or oestrous behaviour. Ovulation rate averaged 2.27 and varied significantly with the month. However, in spite of significant month effect, it was difficult to distinguish a clear seasonal effect except in May during which ovulation rate and oestrous behaviour were slightly depressed. The length of the oestrous cycles fell into two frequency categories : $5-8$ days and 21 days ; $45 \%$ of the short cycles $(<17$ days) lasted from 5 to 8 days. Frequency of short cycles did not vary with the month. Supplementation significantly reduced short-cycle frequency (C : $38 \% ; S: 27 \%$ ).

There were significant rank correlations between some reproductive responses and environmental factors. The most important were between the monthly percentage of goats in oestrus and minimal temperature and maximal hygrometry $(-0.66$ and -0.61 respectively).

It was concluded that creole meat goats maintained in good condition did not show marked seasonal variations in ovulatory activity or oestrous behaviour. Season had only a subtle effect on some reproductive characteristics. Immediate thermal environment of goats seemed able to modify the expression of oestrus probably by modifying thermal comfort.

(1) Present address : I.N.R.A., Physiologie de la Reproduction, Nouzilly, 37380 Monnaie, France. 


\section{Introduction.}

Previous studies showed that creole goats, permanently maintained with males, conceived all year round. However, since some periods of the year were more favourable to conception and good fertility rates, kidding was somewhat seasonal. It was also shown that litter size at kidding varied with the season of conception but depended mainly on nutritional conditions (Chemineau and Xandé, 1982).

The object of the present experiment was to determine if seasonal variation in conception rate and litter size of female goats could be due to variations in sexual activity (estrous behaviour, ovarian activity, ovulation rate), environmental factors and nutrient status.

\section{Material and methods.}

Geography and climate. - The research farm is in the dry part of Guadeloupe $\left(16^{\circ} 10^{\prime} \mathrm{N}, 61^{\circ} 40^{\prime} \mathrm{W}\right)$. Annual rainfall is $1236 \mathrm{~mm}$. Despite large variation between years it is possible to distinguish a rainy season (August-November $=755 \mathrm{~mm}$ ) and a dry season (December-July $=481 \mathrm{~mm}$ ). Maximum air temperature varies from $27{ }^{\circ} \mathrm{C}$ (January) to $32{ }^{\circ} \mathrm{C}$ (August) and minimum air temperature from 21 to $25^{\circ} \mathrm{C}$. Relative humidity is always above $55 \%$ and daylength varies from 11 to $13 \mathrm{~h}$.

Animals. - Thirty adult goats, representative of the creole population (Chemineau et al., 1984) that had kidded at least once, were not allowed to conceive for 2 consecutive years iNovember 1980 to October 1982). The animals weighed $23.9 \mathrm{~kg}$ (range 18.0 to 30.0 ; SD 2.9) at the onset of the experiment and were distributed into two equal groups, C (control) and S (supplemented). Throughout the experiment, they were treated for internal parasites every 2 months and for ticks twice a month.

Pasture and feeding. - During the whole experiment, the goats were maintained on a Pangola pasture (Digitaria decumbens) with a stocking rate varying from $1,060 \mathrm{~kg}$ of liveweight per hectare (both groups) at the onset of the experiment to $1,310 \mathrm{~kg} / \mathrm{ha}$ (group C) and 1,390 kg/ha (group S) at the end of the experiment. Each of the two paddocks was divided into three sub-paddocks, and the animals were transferred from one to another every 10 days. Consequently, when the goats entered a sub-paddock, the pasture averaged 25 days in age. A fertilizer of $90 \mathrm{~N}, 35 \mathrm{P}, 89 \mathrm{~K}$ was spread over each paddock once at the beginning of the experiment.

A forage sample was taken at each pasture cycle (30 days) to measure the percentage of dry matter (DM), crude protein (CP) and crude fiber (CF) (I.N.R.A., 1978). 
Goats of group $\mathrm{S}$ received $0.3 \mathrm{~kg}$ per head and per day of concentrate $(10,600 \mathrm{kj}$ of metabolizable energy $/ \mathrm{kg}, 135 \mathrm{~g}$ of digestible crude protein). This concentrate covered more than $50 \%$ of the estimated requirement for energy and the total need for nitrogen.

Detection of oestrus. - Throughout the experiment, a vasectomized creole buck, fitted with a marking harness (Radford et al., 1960), was kept permanently with the goats of each group. The number of marked females was recorded every morning. The duration of one oestrous cycle was defined as the number of days between two consecutive oestruses.

Detection of ovarian activity. - Laparoscopy was performed monthly on all goats using the technique described by Thimonier and Mauléon (1969) without starvation. The age of corpora lutea was estimated by size and colour (Oldham and Lindsay, 1980).

Climatic parameters. - Rainfall, minimal and maximal temperature, minimal and maximal hygrometry, and solar radiation were recorded daily at animal level. The mean monthly values of these measurements were correlated with reproductive responses.

Analysis of results. - Monthly liveweight and the number of ovulations were analysed by analysis of variance with three factors (Group, Goat, Month) and one interaction (Month $\times$ Group). The monthly percentages of goats in oestrus, of goats ovulating and of those with short oestrous cycles were analysed by analysis of variance, after arc-sinus transformation, with two factors (Group, Month) and one interaction (Month $\times$ Group ; Bachacou et al., 1981).

Relationships between climatic and reproductive responses were analysed with Spearman's rank correlation coefficient (Dagnélie, 1970).

\section{Results.}

Pasture production and liveweight variation. - Average dry matter (DM) and crude protein (CP) content of the forage samples were 40 and $6.6 \%$ respectively, and varied widely from one month to another. Average crude fiber content (CF) was $32 \%$ (table 1 ).

Time significantly affected liveweight and both groups were in liveweight gain between the onset and the end of the experiment. However, feeding regime interacted with the month, indicating that supplemented goats gained more liveweight $(+41 \%)$ that control goats $(+30 \%)$. A significant effect of goats indicated that a sizeable amount of variability exists between animals (table 2 ; fig. 1 ). 
TABLE 1

Dry matter, crude protein and crude fiber content of forage sampled during the experiment. Mean $\pm S D$ and (range).

\begin{tabular}{lcc}
\hline & Control group & Supplemented group \\
\hline Dry matter content \% & $39.0 \pm 14.3$ & $40.2 \pm 15.1$ \\
& $(19-75)$ & $(19-77)$ \\
Crude protein content \% & $6.6 \pm 2.5$ & $6.7 \pm 2.6$ \\
of dry matter & $(3-13)$ & $(3-13)$ \\
$\begin{array}{l}\text { Crude fiber content \% } \\
\text { of dry matter }\end{array}$ & $32.0 \pm 2.0$ & $31.9 \pm 1.7$ \\
\hline
\end{tabular}

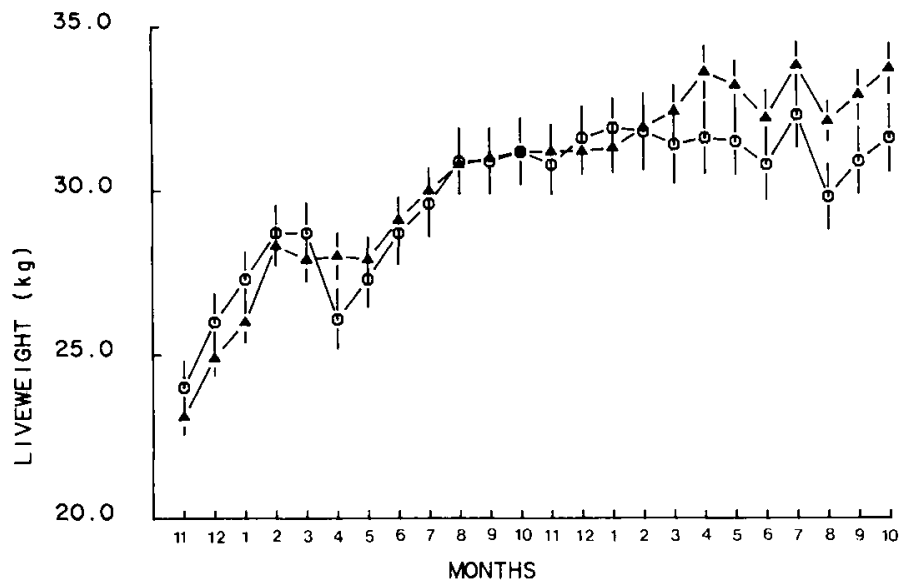

FIG. 1. - Liveweight in creole goats over two experimental years. $\bigcirc$ : control group : $\mathbf{A}$ : supplemented group, $M \pm$ S.E.M.

Monthly ovarian activity. - The percentage of goats ovulating per month was not affected significantly by month or by supplementation. For the two groups and the two experimental years, more than $87 \%$ ovulated monthly (table 2).

Ovulation rate. - A total of 234 ovulatory goats bearing active corpora lutea were observed in group $C$ and 260 in group S. Significant effects of goats and months were detected on the number of ovulations (table 2).

The average ovulation rate per female of group $C$ was 2.15 (SD \pm 0.46 ) and that of group $S$ was 2.38 ( $S D \pm 0.41$ ) but the difference was not significant; the distribution of number of ovulations is indicated in table 3 . The monthly ovulation rate within each group varied among months. Lower ovulation rates were observed in May in group $S$ and in January and May in group C (fig. 2). 
Oestrous activity. - On an average, $82 \%$ of goats showed oestrus at least once per month (C: $1.38 \pm 0.38$ vs $S: 1.23 \pm 0.25$ oestrous periods per month per female), and this did not vary significantly between group $C$ and $S$ at any time during the experiment. The percentage in oestrus was lower than the percentage

TABLE 2

F-values of the analysis of variance for reproductive parameters in creole goats.

\begin{tabular}{|c|c|c|c|c|}
\hline & & D.F. & Mean Square & $F$ Value \\
\hline Liveweight & $\begin{array}{l}\text { Group } \\
\text { Goat in group } \\
\text { Month } \\
\text { Month } \times \text { Group } \\
\text { Error }\end{array}$ & $\begin{array}{r}1 \\
28 \\
23 \\
20 \\
499\end{array}$ & $\begin{array}{c}0.0015 \\
206.88 \\
180.71 \\
4.01 \\
1.12\end{array}$ & $\begin{array}{r}<0.001 \\
185.11^{* * *} \\
161.69^{* * *} \\
3.59^{* * *}\end{array}$ \\
\hline Percentage ovulating & $\begin{array}{l}\text { Group } \\
\text { Month } \\
\text { Month } \times \text { Group } \\
\text { Error }\end{array}$ & $\begin{array}{r}1 \\
11 \\
11 \\
24\end{array}$ & $\begin{array}{l}0.033 \\
0.036 \\
0.029 \\
0.041\end{array}$ & $\begin{array}{l}0.806 \\
0.872 \\
0.699\end{array}$ \\
\hline Number of ovulations & $\begin{array}{l}\text { Group } \\
\text { Goat in group } \\
\text { Month } \\
\text { Month } \times \text { Group } \\
\text { Error }\end{array}$ & $\begin{array}{r}1 \\
28 \\
23 \\
20 \\
499\end{array}$ & $\begin{array}{l}0.0007 \\
4.33 \\
2.79 \\
0.625 \\
0.595\end{array}$ & $\begin{aligned}< & 0.001 \\
7.28^{* * *} & 4.69^{* * *} \\
& 1.05\end{aligned}$ \\
\hline Percentage in oestrus & $\begin{array}{l}\text { Group } \\
\text { Month } \\
\text { Month } \times \text { Group } \\
\text { Error }\end{array}$ & $\begin{array}{r}1 \\
11 \\
11 \\
24\end{array}$ & $\begin{array}{l}0.324 \\
0.438 \\
0.121 \\
0.155\end{array}$ & $\begin{array}{l}2.086 \\
2.823^{*} \\
0.777\end{array}$ \\
\hline $\begin{array}{l}\text { Percentage } \\
\text { of short oestrous cycles }\end{array}$ & $\begin{array}{l}\text { Group } \\
\text { Month } \\
\text { Month } \times \text { Group } \\
\text { Error }\end{array}$ & $\begin{array}{r}1 \\
11 \\
11 \\
24\end{array}$ & $\begin{array}{l}1.565 \\
0.151 \\
0.136 \\
0.146\end{array}$ & $\begin{array}{c}10.682^{* * *} \\
1.034 \\
0.929\end{array}$ \\
\hline
\end{tabular}

${ }^{*}: \mathrm{p}<0.05 \quad{ }^{* * *}: \mathrm{p}<0.001$

TABLE 3

Distribution of the number of ovulations in creole goats (in percentage of total ovulatory periods observed).

\begin{tabular}{cccccc}
\hline & \multicolumn{5}{c}{ Number of ovulations } \\
\cline { 2 - 6 } & 1 & 2 & 3 & 4 & 5 \\
\hline $\begin{array}{c}C \text { group } \\
(N=234)\end{array}$ & 19 & 48 & 29 & 4 & 0 \\
$\quad \mathrm{~S}$ group \\
$(\mathrm{N}=260)$
\end{tabular}

C : Control ; S : supplemented. 


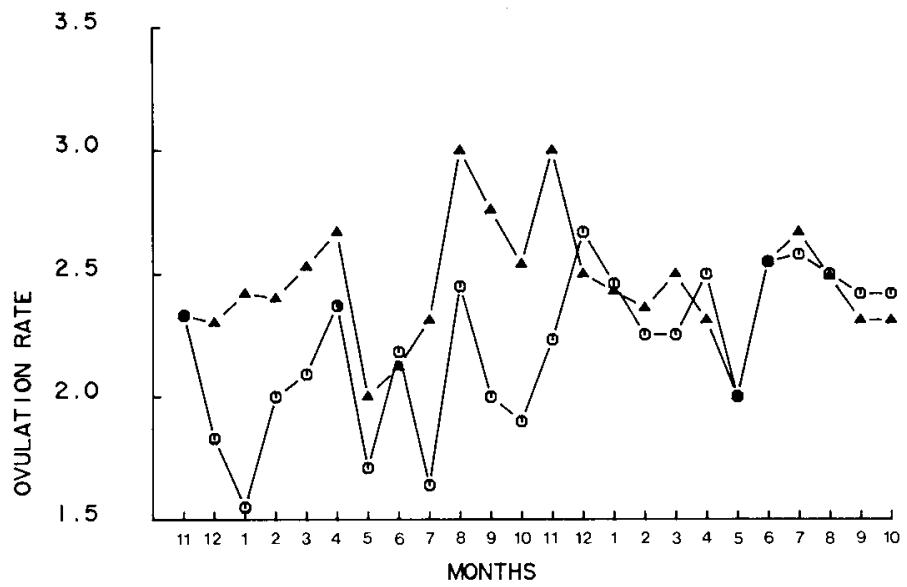

FIG. 2. - Monthly ovulation rate in creole goats over two experimental years. $\bigcirc$ : control group (234 with active corpora lutea) ; $\boldsymbol{\Delta}$ : supplemented group (260 with active corpora lutea).

ovulating every month. The monthly percentage in oestrus within both groups varied with the month (table 2 ; fig. 3 ).

Duration of oestrous cycles. - A total of 473 oestrous cycles were recorded in group $C$ and 406 in group $S$. The relationship between frequency and duration showed two groupings of cycle length : 5 to 8 days, and about 21 days (fig. 4). Forty-five percent of the short cycles (less than 17 days) lasted from 5 to 8 days (131/292).

A significant effect of group was detected on the percentage of short cycles; more short cycles were observed in the control group than in the supplemented group (table $2 ; 38$ vs $27 \% ; p<0.001$ ). A large within-group variation in the percentage of short cycles was observed from one month to another and from one year to another, however no significant effect of month was detected (fig. 3 ).

Relationship between nutritional or climatic parameters and reproduction (table 4). - The average monthly liveweight in the two groups showed a positive relationship with minimal hygrometry and with the percentage of forage dry matter. Group $C$ liveweignt was correlated negatively with nitrogen content.

The percentage of group $C$ goats in oestrus at least once a month was correlated negatively with minimal air temperature and maximal hygrometry.

The monthly percentage of ovulatory group $\mathrm{C}$ goats was correlated positively with forage dry matter content.

The percentage of short cycles in group $\mathrm{C}$ was correlated positively with minimal hygrometry.

FIG. 4. - Frequency of oestrous cycles relative to their duration in creole goats over two experimental years. $\bigcirc$ : control group ; $\mathbf{A}$ : supplemented group $(473$ and 406 cycles, respectively). 

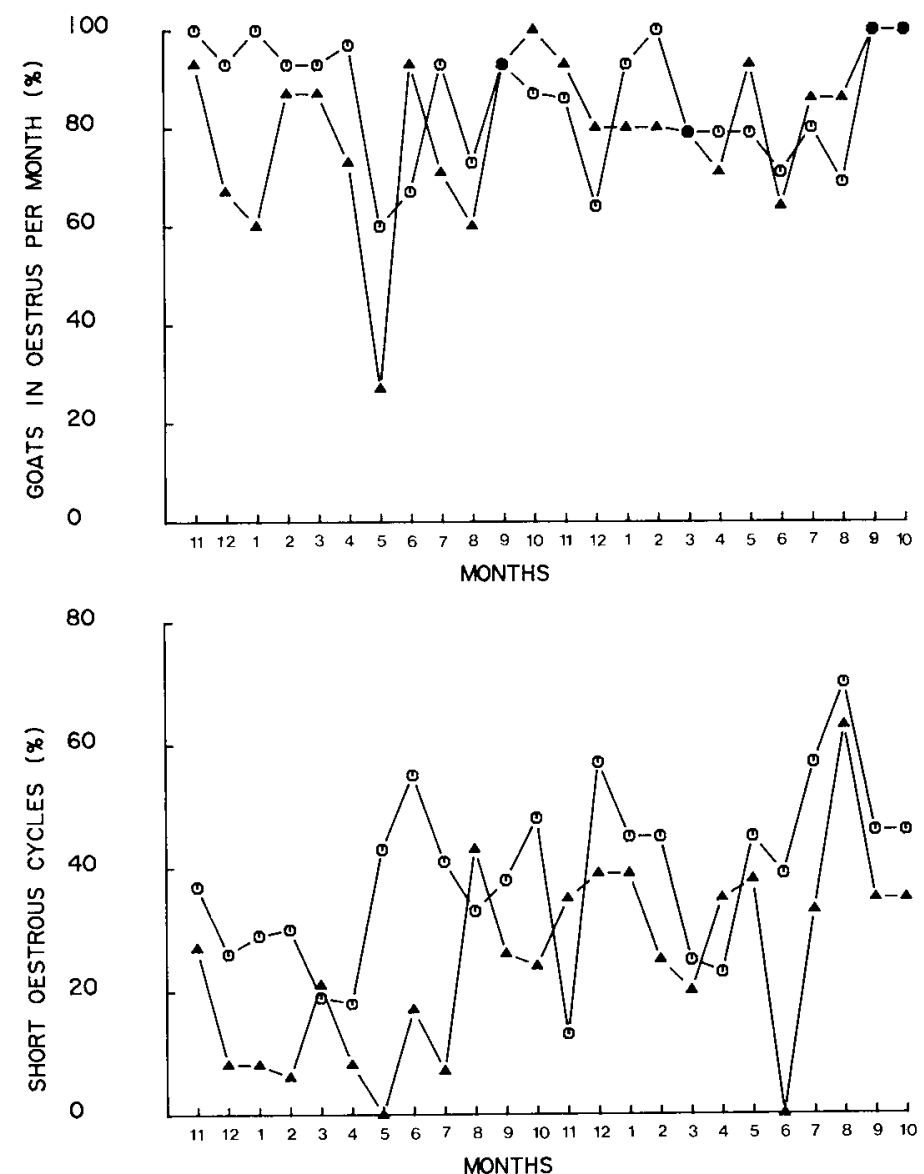

FIG. 3. - Percentage of goats in oestrus at least once per month and monthly percentage of short oestrous cycles over two experimental years. $O$ : control group ; $\boldsymbol{\Lambda}$ : supplemented group.

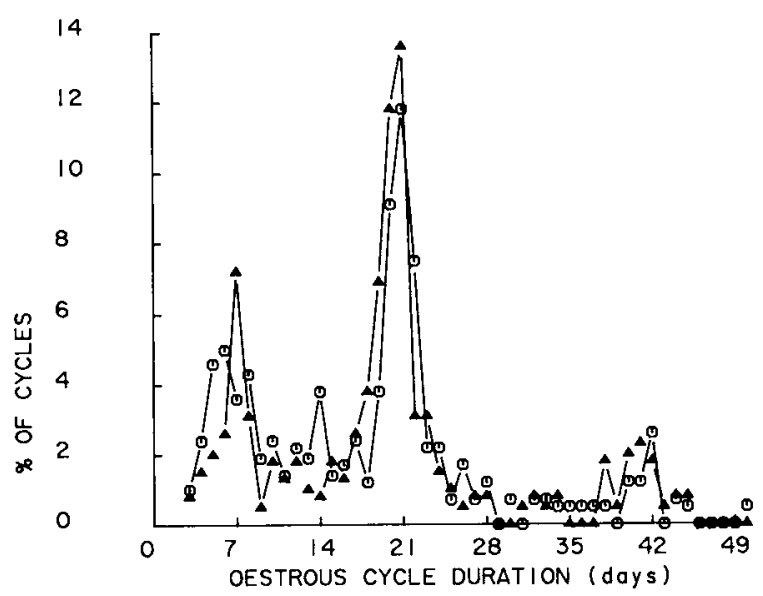


The ovulation rate in group $\mathrm{C}$ was correlated positively with minimal hygrometry and negatively with forage crude protein content.

Other rank correlation coefficients were not significantly different from zero.

\section{TABLE 4}

Significant rank correlation coefficients between environmental response and reproductive characteristics in creole goats.

\begin{tabular}{|c|c|c|c|c|c|}
\hline & Liveweight & $\begin{array}{l}\text { Percentage } \\
\text { in oestrus }\end{array}$ & $\begin{array}{l}\text { Percentage } \\
\text { ovulating }\end{array}$ & $\begin{array}{c}\text { Percentage } \\
\text { of short cycles }\end{array}$ & $\begin{array}{l}\text { Ovulation } \\
\text { rate }\end{array}$ \\
\hline \multicolumn{6}{|l|}{ Forage } \\
\hline DM Content & $\begin{array}{l}0.58(C) \\
0.53(S)\end{array}$ & & $0.46(C)$ & & \\
\hline $\begin{array}{l}\text { CP Content } \\
\text { CF Content }\end{array}$ & $-0.79(\mathrm{C})$ & & & & $-0.48(C)$ \\
\hline $\begin{array}{l}\text { Minimal temperature } \\
\text { Maximal temperature }\end{array}$ & & $-0.66(C)$ & & & \\
\hline Minimal humidity & $\begin{array}{l}0.56 \text { (C) } \\
0.70 \text { (S) }\end{array}$ & & & 0.51 (C) & $0.49(\mathrm{C})$ \\
\hline $\begin{array}{l}\text { Maximal humidity } \\
\text { Solar radiation } \\
\text { Rainfall } \\
\text { Photoperiod }\end{array}$ & & $-0.61(C)$ & & & \\
\hline
\end{tabular}

C : Control group; S : Supplemented group; d.f. : $23 ; r=0.42, P<0.05$ and $r=0.54$, $\mathrm{P}<0.01$.

\section{Discussion.}

Compared to the usual standards of pasture quality in temperate climates (I.N.R.A., 1978), the quality in both the paddocks was very poor throughout the experiment. However, goats in the control group showed a liveweight gain over the 2 experimental years. This probably can be explained by the lack of precise knowledge of creole nutrient requirements and also by the ability of these animals to pick out the best of the plant, whereas we sampled the whole plant. The supplement given to group $\mathrm{S}$ goats did not induce dramatic changes in liveweight compared to that of group $C$, probably because the latter goats satisfied their energy requirement.

Neither group of creole goats showed any large variation in ovarian activity during the whole experiment; more than $87 \%$ of the goats had at least one ovulation per month. The present results differ somewhat from those obtained on the same breed by Cognié (1971) who observed a more marked diminution of ovarian activity in creole goats. The difference with our experiments could be due to the fact that our experimental goats had kidded at least once and consequently were adult, whereas Cognié (1971) used mainly nulliparous animals in their first or second " sexual season ". It is known that adult ewes have less pronounced anovulatory periods than ewe-lambs at their first anoestrous season (Walrave, 1970 ; Khaldi, 1984). 
The monthly percentage of group $C$ goats showing ovarian activity was correlated positively with forage dry matter content. This suggested that ovarian activity was related with the quality of available food. However, this is not certain since the monthly percentage of ovarian activity varied only slightly.

The number of ovulations varied with months and it reached a minimum in May in both groups and both years of the experiment. However, no clear seasonal variation appeared.

The monthly percentage of goats in oestrus (82\%) was slightly lower and more variable than the monthly percentage of ovulatory goats $(87 \%)$. This indicated that there was a slightly larger proportion of silent ovulations. Some of these could be attributed to failure of the bucks to detect oestrus, but this percentage was certainly low as the male/female ratio was elevated and oestrous goats generally were well-marked by the bucks. Silent ovulation existed since ovarian activity can be detected systematically by direct observation of the ovaries by laparoscopy or by detection of luteal phases by monitoring progesterone plasma levels. In ewes, it is generally associated with the resumption of seasonal (Thimonier and Mauléon, 1969) or postpartum (Khaldi, 1984) sexual activity. In the present study, the percentage of females in oestrus per month varied with the month, and as for ovulation rate, a minimum seems to exist in May. However, as for ovulation rate, no clear seasonal variation could be distinguished.

In the present study, the monthly percentage of oestrous goats was correlated negatively with two microclimatic factors : minimal temperature and maximal hygrometry. Such correlations may indicate that a decrease in minimal temperature and in maximal hygrometry (which are two measurements registered during the night) could allow a better dissipation of the heat load received during the day. A recent study in the same breed indicated that rectal temperatures were reduced when both minimal air temperature and maximal hygrometry were low (Chemineau and Ravault, 1984). In the ewe, a decrease in the heat load before oestrus time induced changes in rectal temperatures and the reapparance of oestrus, or increased duration of oestrous behaviour (Sawyer, 1983). Consequently, it is possible that each one of these climatic measurements, considered separately, did not change markedly sexual activity, but that their simultaneous variations (which may be taken into account into an hypothetic climatic index, which remains to be defined) modified thermal comfort. This in turn may alter body temperature and finally reproductive activity.

The distribution of oestrous cycles according to duration revealed a high proportion of short cycles. This high frequency seems to be a characteristic of the caprine species and has been observed in a large number of breeds (GonzalezStagnaro, 1983 ; Corteel, 1973 ; Ricordeau et al., 1984 ; Cognié, 1971 ; Molokwu and Igono, 1978 ; Chemineau, 1983). Ovarian activity during these short oestrous cycles has not been studied systematically. However, as short cycles of identical length are induced by the presence of males (Ott, Nelson and Hixon, 1980 ; Chemineau, 1983), the short cycles in the present experiment are probably associated with the short lifespan of corpora lutea which secrete smaller quantities of progesterone (Chemineau, Poulin and Cognié, 1984). 


\section{Conclusion.}

Adult creole goats maintained in good condition showed intermonth variations in ovulatory activity and oestrous behaviour. However, it was difficult to detect periods in the year during which activity was reduced and indicative of seasonal variations in reproductive activity. Nevertheless, a discrete seasonal effect on ovulation rate and percentage of goats in oestrus was detected with a slight reduction in May.

In our experimental conditions, creole goats seemed to be relatively independent of the season but appeared to be slightly sensitive to immediate variations in their thermal environment. However, this sensitivity remained limited, and difficult conditions of rainfall and temperature do not modify markedly their sexual activity. Thus goats adapt remarkably well to a tropical climate.

Recu en septembre 1985. Accepté en novembre 1985.

Acknowledgements. - I wish to thank J. Thimonier, Y. Cognié and W. W. Thatcher for their help during the experiment and in the preparation of this manuscript, A. Xandé for advice before and during the experiment, and B. Chandi for excellent animal care. This study was financed partially by I.N.R.A. grant ATP "Amélioration des Productions caprines ").

Résumé. Comportement et activité sexuelle au cours de l'année chez le Cabrit Créole de Guadeloupe. I. Comportement d'œstrus et activité ovulatoire.

Une expérience a été conduite pendant deux années consécutives sur 30 chèvres Créoles adultes pour essayer de mettre en évidence d'éventuelles variations saisonnières d'activité oestrale et ovarienne et de savoir si les conditions d'alimentation modifiaient ces activités.

Les animaux, maintenus sur un pâturage de Pangola (Digitaria decumbens) avec une charge de $1060 \mathrm{~kg}$ de poids vif à l'hectare, ont été divisés en deux groupes : C (Contrôles) et $\mathrm{S}$ (Supplémentés). Chaque mois un prélèvement de fourrage est effectué et les animaux sont pesés. Les chèvres du groupe $S$ reçoivent quotidiennement $0,3 \mathrm{~kg}$ d'un concentré du commerce. Le comportement d'œstrus est détecté journellement par relevé des femelles marquées par un bouc vasectomisé muni d'un harnais marqueur, présent dans les lots; l'activité ovarienne est enregistrée tous les mois par observation directe des ovaires par endoscopie.

Des variations importantes de la qualité du fourrage existent d'un mois à l'autre ; le contenu moyen en matières sèches et en cellulose brute sont élevés ( 40 et $32 \%$ ) et le contenu moyen en matières azotées est faible $(6,6 \%)$. En dépit de cette mauvaise qualité du fourrage les femelles des deux groupes sont en gain de poids au cours de l'expérience ( $C$ : $+30 \% ; \mathrm{S}:+41 \%$ ).

Pendant toute l'expérience plus de $87 \%$ des femelles ovulent par mois, ce pourcentage ne varie pas avec le mois d'observation; le pourcentage de femelles au moins une fois en œstrus par mois (en moyenne $82 \%$ ) varie significativement avec le mois de mesure et est inférieur au pourcentage de femelles qui ovulent, ce qui indique l'existence d'ovulations silencieuses. La supplémentation alimentaire n'a pas d'effet sur l'activité ovarienne ou 
cestrale mensuelle. Le taux d'ovulation moyen est de 2,27 et varie significativement avec le mois de mesure. Toutefois, malgré un effet significatif du mois il est difficile de distinguer un effet marqué de la saison, sauf en mai où le taux d'ovulation et le comportement d'œstrus sont légèrement plus faibles. Deux catégories peuvent être distinguées dans la durée des cycles œstraux : $5-8$ jours et 21 jours ; $45 \%$ des cycles courts $<17$ jours durent de 5 à 8 jours. La fréquence mensuelle de cycles courts ne varie pas avec le mois de mesure. La supplémentation alimentaire réduit significativement la fréquence de cycles courts (C: $38 \% ; \mathrm{S}: 27 \%$ ).

II existe des coefficients de corrélation de rang significatifs entre les paramètres de reproduction et les facteurs de l'environnement climatique. Les plus importants sont entre le pourcentage mensuel de femelles en œstrus et la température minimale $(-0,66)$ et l'hygrométrie maximale $(-0,61)$.

Les chèvres Créoles de Guadeloupe maintenues dans de bonnes conditions d'élevage ne manifestent donc pas de variations saisonnières marquées de leur activité ovarienne ou œstrale. La saison exerce seulement un effet discret sur certains paramètres de reproduction. L'environnement thermique immédiat semble cependant capable de modifier l'expression du comportement d'œstrus, probablement par l'intermédiaire d'une modification du confort thermique.

\section{Références}

BACHACOU J., MASSON J. P., MILLIER C., 1981. Manuel de la programmathèque statistique AMANCE 1981. Ed. I.N.R.A. Dept. Biométrie, $516 \mathrm{p}$.

CHEMINEAU P., 1983. Effect on oestrus and ovulation of exposing creole goats to the male at three times of the year. J. Reprod. Fert., 67, 65-72.

CHEMINEAIJ P., COGNIÉ Y., XANDÉ A., PEROUX F., ALEXANDRE G., LEVY F., SHITALOU E., BECHE J. M., SERGENT D., CAMUS E., BARRE N., THIMONIER J., 1984. Le "Cabrit créole " de Guadeloupe et ses caractéristiques zootechniques: monographie. Rev. Elev. Med. vét. Pays trop., 37, 225-238.

CHEMINEAU P., POULIN N., COGNIE Y., 1984. Sécrétion de progestérone au cours du cycle induit par l'introduction du mâle chez la chèvre créole en anoestrus : effets de la saison. Reprod. Nutr. Dévelop., 24, 557-561.

CHEMINEAU P., RAVAULT J. P., 1984. Variations horaires de la température rectale et de la prolactinémie chez le "Cabrit créole " maintenu à l'extérieur en milieu tropical. Reprod. Nutr. Dévelop., 24, 71-80.

CHEMINEAU P., XANDÉ A., 1982. Reproductive efficiency of creole meat goats permanently kept with males. Relationship to a tropical environment. Trop. anim. Prod., 7, 98-104.

COGNIE Y., 1971. Cited by CORTEEL J. M., 1973.

CORTEEL J. M., 1973. L'insémination artificielle caprine: bases physiologiques, état actuel et perspectives d'avenir. World Rev. anim. Prod., 9, 73-99.

DAGNÉLIE P., 1970. Théorie et méthodes statistiques. Vol. II. Presses agron. Gembloux (Belgique) : $451 \mathrm{p}$.

GONZALEZ-STAGNARO C., 1983. Comportamiento reproductivo de las razas locales de ruminantes en el tropico americano. In P. CHEMINEAU, D. GAUTHIER et J. THIMONIER, Reproduction des ruminants en zone tropicale. Coll. I.N.R.A., N 20, 1-84.

I.N.R.A., 1978. Alimentation des Ruminants. Ed. I.N.R.A. Publications, Versailles, 621 p.

KHALDI G., 1984. Variations saisonnières de l'activité ovarienne, du comportement d'cestrus et de la durée de l'anoestrus port-partum des femelles de race Barbarine: influences du niveau alimentaire et de la présence du mâle. Th. Doct. Etat Univ. Sci. Techni. du Languedoc, Montpellier II, $168 \mathrm{p}$. 
MOLOKWU E.C.I., IGONO M.O., 1978. Reproductive performances and patterns in the brown goat of Nigerian savanna zone. In L. VERDE and A. FERNANDEZ, $4^{\text {th }}$ World Congr. anim. Prod., 20-26 Avril, Buenos Aires, Vol. 2, 1-11.

OLDHAM C. M., LINDSAY D. R., 1980. Laparoscopy in the ewe : a photographic record of the ovarian activity of ewes experiencing normal or abnormal oestrous cycles. Anim. Reprod. Sci., 3, 119-124.

OTT R. S., NELSON D. R., HIXON J. E., 1980. Effect of presence of the male on initiation of oestrous cycle activity of goats. Theriogenology, 13, 183-190.

RADFORD M. M., WATSON R. H., WOOD G. E., 1960. A crayon and associated harness for the detection of mating under field conditions. Aust. vet. J., 36, 56-66.

RICORDEAU G., BOUILLON J., GAILLARD A., LAJOUS A., LAJOUS D., 1984 . Modalités et caractéristiques de reproduction chez les caprins. Aspects génétiques. B.T.I., 391, 367-383.

SAWYER G. J., 1983. The influence of radiant heat load on reproduction in the Merino ewe. In P. CHEMINEAU, D. GAUTHIER et J. THIMONIER, Reproduction des ruminants en zone tropicale. Coll. I.N.R.A. No 20, 225-238.

THIMONIER J., MAULÉON P., 1969. Variations saisonnières du comportement d'œstrus et des activités ovarienne et hypophysaire chez les ovins. Ann. Biol. anim. Bioch. Biophys., 9, 233250.

WALRAVE Y., 1970. Variations saisonnières de l'activité sexuelle des races ovines du Massif Central. Mémoire de fin d'études. Institut Technique de Pratique Agricole, Paris. 